\title{
Evaluation of the Implementation of Science Subject Teacher Education and Training in Balai Diklat Keagamaan Palembang
}

\author{
Mardianah \\ MTs Negeri 3 Musi Banyuasin, Indonesia \\ Email: marvelstourandtravel@gmail.com \\ Happy Fitria \\ Universitas PGRI Palembang, Indonesia \\ e-mail: happyfitriamufly@univpgri-palembang.ac.id \\ Rohana \\ Universitas PGRI Palembang, Indonesia \\ e-mail: rohana@univpgri-palembang.ac.id \\ Article History: Received on 8 November 2021, Revised on 29 January 2022 \\ Published on 8 February 2022
}

\begin{abstract}
This study evaluates the quality of education and teacher training at the IPA's Balai Diklat Keagamaan in Palembang. This study employs a qualitative design. The results of the study show that the context program aims to improve people's confidence and skills. However, the process of research is inefficient, therefore the product that is produced does not meet the minimum standards that were expected.
\end{abstract}

Keywords: Evaluation Research, Education and Training, Teachers

\section{A. Introduction}

Education, with all of its difficulties, is a fascinating subject to discuss. The teacher is the topic of discussion in education. A teacher is someone who helps everyone since he or she helps others reach their goals in life. Teachers are professional educators who must possess a variety of talents or competences in order to carry out their educational responsibilities. Article 8 paragraph (1) of Law Number 14 of 2005 Concerning Instructors and Lecturers establishes four categories of competences that teachers must possess, namely Pedagogical Competence, Personality Competence, Social Competence, and Professional Competence (Rohma et al, 2020; Mukartik et al, 2020; Listiningrum et al, 2020).

Human resource development is must exist and occur in any business, taking both internal and external issues into account. Internal elements include the organization's mission and goals, strategy for accomplishing goals, the kind and type of technology employed, and so on. Meanwhile, external elements include government regulations, local culture, and scientific and technological advancement. Human resource development via education and training may be viewed as an investment. As a result, every firm that wishes to grow may boost the output of its machinery via ongoing education and training (Abubakar, 2020).

Educators, as the frontline of education implementation, must be empowered, with different trainings, retraining, releases, and so on (Suparlan, 2011). Regulations governing the improvement of educator quality are stipulated in Law Number 20 of 2003 concerning the 
Volume 3 (1) 2022

E-ISSN: 2723-6919 P-ISSN: 2746-0827

National Education System, Chapter I General Provisions, that educators are educational staff with qualifications as teachers, lecturers, counselors, studies, instructors, facilitators, and facilitators Other appointments according to their specificity, and participate in the process of implementing education.

Schools must pay attention to variables that might increase teacher performance in developing all of their potential in order to improve teacher performance in terms of competence and skills in the learning process. One of these is via education and training (Sagala, 2013). As emphasized in the Ministry of Religion's Strategic Plan and Ministry of Religion's Training and Training in 2014-2019, improving the quality of technical and religious training training by (1) improving the organization of Human Resource Training; (2) improving academic qualifications and expertise among Widyaiswara; (3) improving the quality of the training system; (4) Diversification of training delivery methods, including on-the-job and remote training; (5) Using research findings for training purposes; and (6) Improving the training quality of quality assurance systems (Suryani, 2021).

Dahlan et al. (2020) state that education and training will develop teacher knowledge, which may then be applied to students during the learning process. These instructors will create good results if they follow the norms of professionalism in carrying out their tasks and activities. Teachers' success in the learning process is mostly affected by their effectiveness as educators. Teacher performance is defined as a teacher's capacity to carry out learning activities at school and is accountable to pupils under his supervision by boosting student learning accomplishments. The most significant factor in facilitating the development of an effective learning process is teacher learning performance.

The Education and Training Center of the Research and Development Agency, as well as the Indonesian Religious Education and Training Center, have provided education and training for teachers under the Ministry of Religion, although not all instructors have had the opportunity to participate. Inequitable access to education and training for madrasa instructors may indicate a lack of teacher professionalism in teaching and learning activities. This study aims to analyze the process of arranging training so far, which has become important to conduct, particularly in order to quantify and identify the influence of the training program on the performance or performance of Madrasah Ibtidaiyah, Madrasah Tsanawiyah, and Madrasah Aliyah instructors (Nurhialiati, 2019).

However, in fact, Technical Training implementation is still falling short of expectations since it was not prepared based on a requirements analysis and was not created in an integrated manner by incorporating many associated components such as organizers, widyaiswara, and training participants. According to the findings of a 2005 study conducted by the Ministry of Religion's Research and Development Agency and Training on the Implementation of Primary/SLTP Science Teacher Training and Education, the trainings held had not been prepared based on a needs analysis and had not been designed in an integrated manner by involving various related components.

According to article 1 paragraph 1 of the Decree of the Minister of Religion of the Republic of Indonesia Number 1 of 2003, Education and Training, hereinafter referred to as Education and Training, is the implementation of teaching and learning processes in order to improve the competence of Civil Servants within the Ministry of Religion, which is carried out at least 40 hours of lessons, with every hour 45 minutes. 
Religious Education and Training Agencies of the Ministry of Religion Research Results Regarding Evaluation of the Implementation of the MTS Spa Technical Training Results (2018) Teachers coordinated by Pusdiklat and Religious Training Centers around Indonesia demonstrated a considerable improvement in competency by scoring over 80 . The reason for this is because the science instructors reported an increase in competency in terms of knowledge, abilities, and attitudes after attending the program. The attitude variable gets the highest score among the three supporting competency factors, followed by the knowledge and skills variable.

The findings demonstrated that a large improvement in teacher competency was accompanied by an increase in their capacity to implement it in learning activities in Madrasahs. However, the training's results have not had a substantial influence on enhancing the quality of madrasas. Because, for certain madrasah, the training outcomes are difficult to execute due to numerous problems such as insufficient laboratory facilities, science instructors' competence to handle science equipment that is still limited, and Madrasah rules.

In terms of the training implementation process, the findings demonstrate that it has an impact on the enhancement of MTS science teacher competency, with a score of 79. However, the training's implementation is still plagued by several issues, including: 1) recruitment of UNRGEE participants, 2) training has not been able to reach all science teachers and only feels like there are a handful of teachers, 3) the frequency/volume of training is still limited, 4) the training's implementation is still not supported by adequate facilities, and 5) the training's implementation is still focused on learning theory/concepts and not on teaching.

The results of the study recommend, first: the needs of the Ministry of Religion; 1) Develop the procurement of a Science Laboratory Procurement Program for MTS Representatives complete with all the equipment, because there are still many MTS that do not have a science laboratory, or already have but their conditions are not feasible, 2) Build Balai Diklat Keagamaan in various regions, At least one province has one Balai Diklat Keagamaan, so that implementation of training is able to reach more participants.

Second, Pusdiklat and BDK must: 1) accurately recruit potential training participants by considering academic and administrative criteria/requirements; 2) Multiply training through on-the-job training by two. 3) Increase the number of scientific and technology training opportunities; 3) Create a policy for the year-round implementation of technical training for science instructors. 4) Plan technical training for science instructors that lasts at least two weeks. 5) Provide training for teachers at the national, regional, and regional levels. 6) Organizing training by incorporating numerous parties as training partners, such as universities, LPMP, research institutions, and so on. 7) Provide science representatives and library laboratories for training, as well as assistance for training activities.

Third, for alumni education and teacher training, it is preferred that the information gained via training be used with other scientific teachers, so that science teachers' competency is disseminated equitably in each madrasa. The Palembang Religious Education and Training Center will encounter severe duties and service needs in the future. This is due to stakeholder wishes as a result of the growth of communal life. As a result, Palembang religious education and religious training halls, as service providers, must take preparation and cautious planning procedures in order to realize the aims and objectives of the education and training program. 
The goal is to create equipment that can carry out their jobs and functions. As a result, the function of this institution in the design and development of equipment becomes critical.

It is critical to discuss education and training for Madrasah instructors in order to increase the quality of religious instruction in Madrasahs. The laws regulating teacher education and training are clear, yet not all madrasa instructors have access to them. This is explained in Minister of Religion Regulation Number 43 of 2016 concerning Information System Management Education and Training at the Ministry of Religion, Article 1, paragraph (2), "Education and Training, hereinafter referred to as Diklat, is the implementation of learning and training in order to develop employee competencies in accordance with job requirements." The extent to which the Palembang Religious Training Center issues teaching staff or human resources in adjusting to advances in educational technology and the demands of educational personnel needs so that they can provide optimal education and training services by utilizing the sophistication of existing equipment is one of the challenges and problems that arise.

The Palembang Religious Education and Training Center must continue to exist since its needs are still extremely important in the face of numerous class constraints, prices, and the location of the tasks of workers who must be taught. However, in order to achieve greater outcomes in the future, a number of adjustments in the organization of Religious Education and Training are required. The Palembang Religious Education and Training Center's operations are constantly being improved and expanded in order to suit the expectations and needs of religious technical people. With the fast growth of learning techniques and educational technology, the Palembang Religious Education and Training Center's services in the field of education and training must be more dependable and innovative in order to compete with other education and training providers.

During the initial visit to the study site, it was discovered that there were still a limited number of workers and Widyaiswara, a low quality of human resources owned, a lack of infrastructure, and a shortage of education and training budget, so that not all instructors could attend the training. The given facilities and infrastructure do not fulfill the standards for cleanliness and user satisfaction. The cleanliness of the participants' living environment and classrooms has a significant impact on their comfort when engaging in learning. Participants are more focused on participating in the training when they have access to classroom facilities and a clean and pleasant place to stay, which facilitates the process of transferring information and skills. The Palembang Religious Education and Training Center's teaching staff, or Widyaiswara, is a vital supporting component in the execution of efficient teacher training and subject matter in accordance with its aims. However, there are still teaching personnel with S1 certifications to back this up. There are 25 Widyaiswara in the Palembang Religious Education and Training Center. There are 16 persons with S2 credentials within this group, whereas 9 Widyaiswara still have S1 qualifications. This has to be addressed because Widyaiswara, in his teaching and learning activities, is an education and training teacher who adheres to general education and training teacher standards (Interview, 23 June 2021, to the Palembang Ministry of Religion Education and Training secretariat).

Based on the observations, it is possible to infer that the staff of the Palembang Religious Education and Training Center work full-time, are disciplined, and carry out operations in accordance with the technical instructions in each area and sub-part. However, as Civil Servants, compliance and performance in their tasks are often influenced by laws and punishments, rather than by the spirit of work motivation as a Central Civil Servant geared to 

administratively and in the educational process, are regular.

Subsequent events demonstrate that the evaluation research on the execution of the training program, notably the training group for religious technical staff, was only completed at the end of 2007. Academic services are services that directly influence the core product, namely the trained staff of the Ministry of Religion of South Sumatra Province and Palembang City, when compared to the other services that must be supplied in the execution of education and training status.

Problems that develop in a program may be utilized as a tool to improve the program's efficacy and efficiency by mapping the problem, then seeking for solutions and eliminating existing faults. The program assessment results can be utilized as input for continued program development as well as a foundation for making program-related choices. In order to deliver the finest teacher competence development training program, the teacher competency improvement training program must also be reviewed (Sulastri et al, 2020).

The Palembang Religious Education and Training Center's initiatives to improve services to training participants include the use of modern learning media. This hall, however, has not been supported by a competent and experienced teaching staff. Even if the work plan is flawless and the equipment is cutting-edge, it will be meaningless if it is not backed up by dependable human resources. As a result, the employment of innovative technology at the Palembang Religious Education and Training Center must be complemented by an improvement in the quality of human resources. Aside from that, the attitude of education and training managers and organizers who have not regularly coordinated the planning and evaluation of the implementation of the education and training so that the real problems in the implementation of the education and training are not known early and it is difficult to make adjustments in the implementation steps quickly and precisely (Munir , 2013).

The program evaluation methodology is used for training evaluation. Many specialists have created program assessment models. Each evaluation model has benefits and drawbacks, and the usage of a model may be chosen by the demands of the intended program assessment objectives. The evaluation methodology is chosen based on the evaluation emphasis necessary. Researchers seek to build an assessment model for the implementation of the scientific teacher training program that meets their demands in order to fulfill the needs of assessing the science teacher training program.

The poor quality of education and training implementation will have an impact on the product results, both in terms of output (training participants) and outcomes (students). Thus, whether or not the results of the education and training will effect the product results will be determined by the quality of the training's execution. Based on the aforementioned hypothesis, this study investigates the assessment of education and training implementation in terms of input, process, and outcome components.

The purpose of this study is to assess the quality of education and training results, as well as to analyze features of input, process, and product (output), and to provide a policy approach for education and training implementation. The findings are intended to be beneficial as decisionmaking information for improving teacher competency improvement programs through education and training, particularly for instructors of Religion and General topics in Madrasahs. 


\section{B. Methods}

This is a qualitative study, with data collected in the form of words and pictures rather than statistics (Moleong, 2016). This study lasted three months, from July to September 2021. Because the primary goal of this research is to collect data, data collecting procedures are critical. Researchers will not be able to obtain data that fulfills data standards unless they are familiar with data gathering methodologies (Sugiyono, 2015). Furthermore, Sugiyono noted that in qualitative research, data was collected in natural circumstances using primary data sources, and further data gathering procedures included observation, interviews, and recording. Data analysis was carried out concurrently with data collection in this investigation. This study's analytical model is based on an interactive analysis model. According to Miles and Huberman (2018). Data reduction, data presentation, and deriving conclusions are all ways to depict the procedures employed in data analysis.

\section{Results and Discussion}

\section{Context of Implementation of Science Subject Teacher Education and Training at the Palembang Religious Education and Training Center}

Clarity around the goal of organizing Science Subject Teacher Training. That context evaluation is an assessment of needs and the relevance of goals to the needs that occur in a specific environment, which is accomplished by describing the relevant context, identifying the target population, assessing needs, identifying opportunities to address needs, diagnosing problems that underpin the needs, and then assessing whether the program objectives are adequate. In response to the requirement for evaluation of education and training at the Palembang religious training center.

When viewed through the context component, the MTS science teacher training program was held at the Palembang Religious Education and Training Hall with the goal of improving the quality and competence of human resources and non-Civil Servant of the Ministry of Religion in the Work Area of the Palembang Religious Training Center, which was not in accordance with the needs of stakeholders.

\section{Input for the Implementation of Science Subject Teacher Education and Training at the Palembang Religious Education and Training Center}

The education and training curriculum used in the scientific teacher training and education training at the Palembang Religious Education and Training Center is still ineffective in providing high-quality education and training. The drafting team must construct or revise this education and training curriculum by altering the creation of effective knowledge and learning so that participants can grasp the training.

It has been properly organized for the requirements of participants in the implementation of this Science Subject Teacher training. In order to offer ideal training for training participants, the committee's selection has also been guided and modified to the requirements and wishes of the relevant agencies. The criteria are also communicated to training participants via a circular.

The Palembang Religious Education and Training Center's implementation of Science Subject Teacher Training is still ineffective due to a lack of human resources. Human resources, 
Volume 3 (1) 2022

E-ISSN: 2723-6919 P-ISSN: 2746-0827

particularly for training and education teaching professionals, are still in short supply. Furthermore, there must be motivation and career development for human resources at the training center in order for them to carry out their jobs properly (Yasri, 2017). The aspect of Facilities and Infrastructure has been strengthened in the execution of Science Subject Teacher Training at the Palembang Religious Education and Training Center. Very sufficient, in line with the training and education mission, to establish the Education and Training Center as a reform agent and administrative workshop for the Ministry of Religion's work unit in its region.

\section{The Process of Organizing Education and Training for Science Subject Teachers at the Palembang Religious Education and Training Center}

The Palembang City Religious Education and Training Center's science topic teacher training has been going well in terms of education and training plans. The planning is based on the actual requirements of the training participants, and the evaluation of the previous year's training implementation is used as a reference in the formulation of this year's education and training plan. Furthermore, the Palembang city's religious training center team's coordination was made more integrated and integrated in accordance with the education and training plan that had been established.

The Palembang Religious Education and Training Center's execution of science subject teacher training is still ineffective. This is due to a number of circumstances, the resolution of which is the responsibility of the Palembang City Religious Education and Training Center. One of the problems that must be addressed, according to the informant above, is the academic service and teaching staff, who must be more professional since it entails accomplishing the main aims of arranging scientific course teacher training (Suriatna, 2005).

Product Implementation of Science Subject Teacher Education and Training at the Palembang Religious Education and Training Center

The fulfillment of aims and objectives in the execution of science subject teacher training at the Palembang Religious Education and Training Center is still ineffective in attaining what the organization has set. What the Education and Training Center has to do is review the training's implementation so that it can enhance the training's quality and satisfy the expectations of all training participants in the future.

Employees' degree of competency in implementing science topic teacher training at the Palembang Religious Education and Training Center is still ineffective. The training plans and procedures that have been established or are being implemented have not been able to assist employees in obtaining their competences in accordance with current developments. Furthermore, the effect of motivation on training participants, as well as work environment elements affecting training participants, must be taken into account for the future (Hidayati, 2020).

\section{Conclusion}

The context of the Science Subject Teacher training program held at the Palembang Religious Education and Training Center with the aim of improving the quality and competence of civil servants and non-civil servants of the Ministry of Religion in the work area of the Palembang Religious Education and Training Center is still ineffective, based on the input in this study, 
Volume 3 (1) 2022

E-ISSN: 2723-6919 P-ISSN: 2746-0827

the factors that remain an obstacle are the educatio In the meanwhile, the indications for participation needs have been functioning well. It is still ineffective at this level of the implementation process since there are several hurdles that impede the training's execution. Although education and training planning has been excellent, it has not been supported by good execution. As a result, the final product did not achieve its maximum value as intended.

\section{E. Acknowledgement}

Thank to Principal of MTs Negeri 3 Musi Banyuasin, Rector Universitas PGRI Palembang, Director of Postgraduate Program and Chief of Study Program Management of Education Universitas PGRI Palembang and friends who have supported us to do this valuable project.

\section{References}

Abubakar, A. (2020). Penyelenggaraan Diklat Guru Mata Pelajaran Madrasah Di Sulawesi Tenggara [Implementation of Madrasah Subject Teacher Training in Southeast Sulawesi]. EDUCANDUM, 6(1), 89-105.

Dahlan, M., Arafat, Y., \& Eddy, S. (2020). Pengaruh Budaya Sekolah dan Diklat terhadap Kinerja Guru [The Influence of School Culture and Education and Training on Teacher Performance]. Journal of Education Research, 1(3), 218-225.

Decree of the Minister of Religion of the Republic of Indonesia Number 1 of 2003, Education and Training

Hidayati, U. (2020). Evaluasi Implementasi Hasil Diklat Teknis Guru IPA Madrasah Tsanawiyah [Evaluation of the Implementation of the Results of the Tsanawiyah Madrasah Science Teacher Training]. EDUKASI: Jurnal Penelitian Pendidikan Agama dan Keagamaan, 18(2), 238-256.

Law Number 14 of 2005 Concerning Instructors and Lecturers

Law Number 20 of 2003 concerning the National Education System

Listiningrum, H. D., Wisetsri, W., \& Boussanlegue, T. (2020). Principal's Entrepreneurship Competence in Improving Teacher's Entrepreneurial Skill in High Schools. Journal of Social Work and Science Education, 1(1), 87-95. https://doi.org/10.52690/jswse.v1i1.20

Moleong, L. J. (2016). Metodologi Penelitian Kualitatif [Qualitative Research Methodology]. Bandung: Remaja Rosdakarya.

Miles, M.B., Huberman, A. M., \& Saldana, J. (2018). Qualitative Data Analysis: A Methods Sourcebook. Edition 3rd. Los Angeles: Sage Publications Inc.

Minister of Religion Regulation Number 43 of 2016 concerning Information System Management Education and Training. 
Volume 3 (1) 2022

E-ISSN: 2723-6919 P-ISSN: 2746-0827

Murkatik, K., Harapan, E., \& Wardiah, D. (2020). The Influence of Professional and Pedagogic Competence on Teacher's Performance. Journal of Social Work and Science Education, 1(1), 58-69. https://doi.org/10.52690/jswse.v1i1.10

Munir. (2013). Multimedia dan Konsep Aplikasi dalam Pendidikan [Multimedia and Application Concepts in Education]. Bandung: Alfabeta.

Nurhilaliati, N. (2019). Kualitas Kepemimpinan Kepala Madrasah Perempuan di Lingkungan Pondok Pesantren [Leadership Quality of Female Madrasah Heads in Islamic Boarding Schools]. Edukasi, 17(1), 294561.

Religious Education and Training Agencies of the Ministry of Religion Research Results Regarding Evaluation of the Implementation of the MTS Spa Technical Training Results (2018).

Results of Research on Religious Education and Religious Education and Training Agencies of the Ministry of Religion regarding Evaluation of the Implementation of the Results of the MTS Spa Technical Training (2018) for Teachers organized by Pusdiklat and Religious Training Centers throughout Indonesia.

Rivayanti., Arafat, Y., \& Puspita, Y. (2020). Manajemen Kepemimpinan Kepala Sekolah dalam Pembinaan Profesionalisme Guru [Principal Leadership Management in Teacher Professionalism Development]. Journal of Innovation in Teaching and Instructional Media, 1(1), 10-17. https://doi.org/10.52690/jitim.v1i1.25

Rohma, S., Harapan, E., \& Wardiah, D. (2020). The Influence of School-Based Management and Teacher's Professionalism toward Teacher's Performance. Journal of Social Work and Science Education, 1(1), 13-23. https://doi.org/10.52690/jswse.v1i1.6

Sagala, S. (2013). Kemampuan Profesional Guru dan Tenaga Kependidikan [Professional Ability of Teachers and Education Personnel]. Bandung: Alfabeta.

Sugiyono. (2015). Metode Penelitian Kuantitatif, Kualitatif dan $R \& D$ [Quantitative, Qualitative and R\&D Research Methods]. Bandung: Alfabeta.

Sulastri, S., Fitria, H., \& Martha, A. (2020). Kompetensi Profesional Guru dalam Meningkatkan Mutu Pendidikan [Teacher Professional Competence in Improving Education Quality]. Journal of Education Research, 1(3), 258-264.

Suparlan. (2011). Tanya Jawab Pengembangan Kurikulum dan Materi Pembelajaran: Curriculum and Learning Material Development [Questions and Answers on Curriculum Development and Learning Materials: Curriculum and Learning Material Development]. Jakarta: Bumi Aksara.

Surianta, E. (2005). Upaya peningkatan efektivitas manajemen pendidikan dan pelatihan (studi kasus pada Balai Pendidikan dan Pelatihan Keagamaan Medan) [Efforts to increase the effectiveness of education and training management (case study at the Medan Religious Education and Training Center)]. Doctoral Dissertation, UNIMED. 
Journal of Social Work and Science Education

Volume 3 (1) 2022

E-ISSN: 2723-6919 P-ISSN: 2746-0827

Suryani, L. (2021). Pengaruh Diklat Peningkatan Kompetensi Guru IPA MTs Terhadap Pemahaman Guru IPA MTs Dalam Membuat Rencana Pelaksanaan Pembelajaran (RPP) [The Effect of Education and Training on Improving the Competence of MTs Science Teachers on the Understanding of MTs Science Teachers in Making Learning Implementation Plans (RPP)]. Jurnal Perspektif, 14(2), 232-249.

Yasri, Y. (2017). Evaluasi Pasca Diklat Guru Muda Madrasah Aspek Kompetensi [Evaluation of Post-Training for Madrasah Young Teachers Aspects of Competence]. Andragogi: Jurnal Diklat Teknis Pendidikan dan Keagamaan, 5(2), 1-16. 